\title{
The Triadic Approach to Cash Management: Communication, Advocacy, and Legal Aspects
}

\author{
IANA KOBUSHKO ${ }^{1}$, INNA TIUTIUNYK², IHOR KOBUSHKO ${ }^{3}$, MYKOLA STARINSKYI ${ }^{4}$, \\ ZHANNA ZAVALNA ${ }^{5}$ \\ ${ }^{1}$ Oleg Balatskyi Department of Management, SUMY STATE UNIVERSITY, UKRAINE, \\ E-mail: iana.kobushko@management.sumdu.edu.ua \\ ${ }^{2}$ Department of Finance and Entrepreneurship, SUMY STATE UNIVERSITY, UKRAINE, \\ E-mail: i.karpenko@finance.sumdu.edu.ua \\ ${ }^{3}$ Department of Finance and Entrepreneurship, SUMY STATE UNIVERSITY, UKRAINE, \\ E-mail: i.kobushko@finance.sumdu.edu.ua \\ ${ }^{4}$ Department of Administrative, Economic Law and Financial and Economic Security, SUMY STATE UNIVERSITY, \\ UKRAINE, E-mail: n.starynskyi@uabs.sumdu.edu.ua \\ ${ }^{5}$ Department of Civil Law, V. N. KARAZIN KHARKIV NATIONAL UNIVERSITY, UKRAINE, \\ E-mail: zavalna@karazin.ua
}

\begin{abstract}
The article deals with the study of the ability of cash to be a multifunctional instrument of economic policy, propaganda and legalization of proceeds of crime. Based on the cash analysis of the Republic of Belarus, Georgia and Ukraine, the most common signs and images that increase the confidence of the population and form convictions about the stability of the currency have been identified. Cash has been found to be an instrument for promoting national history and achievements of the country for a long time, considerable territory and one-sided influence. The efficiency of using cash to reliably convey information and maximize its absorption by the population has been proved. The reasons, features and consequences of using cash as a tool for money laundering were investigated. The effect of the volume of cash in circulation on the level of the shadow economy on the example of different countries has been estimated. In the article, the authors argue that money is a useful tool for propaganda. They are a significant source of information about a particular country. Money can be used by the authorities of a particular country to create the necessary political narratives. This tool has a long period of influence, which is purposeful. The authors note that it is necessary to take into account inflation in the country in order to understand how long the population will use a particular denomination of money. The authors concluded that there is a different relationship between the level of shadowing of the economy and indicators of the state of money circulation. For most indicators, this relationship was linear. Calculations showed the absence of an asymmetric relationship between the indicators. For some countries (Belarus, Bulgaria, Georgia, Switzerland, Japan), the calculations showed a nonlinear relationship between the level of shadowing of the economy and the functioning of the domestic foreign exchange market.
\end{abstract}

Keywords: Cash; Advocacy; Communication; Shadow schemes; Legalization of proceeds of crime.

JEL Classification: 017, E51. 


\title{
El Enfoque Triádico de la Gestión del Efectivo: Comunicación, Defensa y Aspectos Legales
}

\author{
IANA KOBUSHKO ${ }^{1}$, INNA TIUTIUNYK ${ }^{2}$, IHOR KOBUSHKO ${ }^{3}$, MYKOLA STARINSKYI ${ }^{4}$, \\ ZHANNA ZAVALNA ${ }^{5}$ \\ ${ }^{1}$ Oleg Balatskyi Department of Management, SUMY STATE UNIVERSITY, UKRAINE, \\ E-mail: iana.kobushko@management.sumdu.edu.ua \\ ${ }^{2}$ Department of Finance and Entrepreneurship, SUMY STATE UNIVERSITY, UKRAINE, \\ E-mail: i.karpenko@finance.sumdu.edu.ua \\ ${ }^{3}$ Department of Finance and Entrepreneurship, SUMY STATE UNIVERSITY, UKRAINE, \\ E-mail: i.kobushko@finance.sumdu.edu.ua \\ ${ }^{4}$ Department of Administrative, Economic Law and Financial and Economic Security, SUMY STATE UNIVERSITY, \\ UKRAINE, E-mail: n.starynskyi@uabs.sumdu.edu.ua \\ ${ }^{5}$ Department of Civil Law, V. N. KARAZIN KHARKIV NATIONAL UNIVERSITY, UKRAINE, \\ E-mail: zavalna@karazin.ua
}

\begin{abstract}
RESUMEN
El artículo aborda el estudio de la capacidad del dinero en efectivo de ser un instrumento multifuncional de política económica, propaganda y legalización del producto del delito. A partir del análisis del efectivo de la República de Bielorrusia, Georgia y Ucrania, se han identificado los signos e imágenes más comunes que aumentan la confianza de la población y forman convicciones sobre la estabilidad de la moneda. Se ha comprobado que el efectivo es un instrumento de promoción de la historia nacional y de los logros del país durante mucho tiempo, un territorio considerable y una influencia unilateral. Se ha demostrado la eficacia del uso del efectivo para transmitir información de forma fiable y maximizar su absorción por parte de la población. Se han investigado las razones, las características y las consecuencias de la utilización del dinero en efectivo como instrumento para el blanqueo de capitales. Se ha estimado el efecto del volumen de efectivo en circulación sobre el nivel de la economía sumergida en el ejemplo de diferentes países. En el artículo, los autores sostienen que el dinero es una herramienta útil para la propaganda. Es una fuente importante de información sobre un determinado país. El dinero puede ser utilizado por las autoridades de un determinado país para crear las narrativas políticas necesarias. Esta herramienta tiene un largo periodo de influencia, que es intencionada. Los autores señalan que es necesario tener en cuenta la inflación del país para entender durante cuánto tiempo la población utilizará una denominación concreta de dinero. Los autores concluyeron que existe una relación diferente entre el nivel de sombra de la economía y los indicadores del estado de circulación del dinero. Para la mayoría de los indicadores, esta relación era lineal. Los cálculos mostraron la ausencia de una relación asimétrica entre los indicadores. Para algunos países (Bielorrusia, Bulgaria, Georgia, Suiza, Japón), los cálculos mostraron una relación no lineal entre el nivel de sombra de la economía y el funcionamiento del mercado nacional de divisas.
\end{abstract}

Palabras claves: Dinero en efectivo; Promoción; Comunicación; Esquemas en la sombra; Legalización del producto del delito.

Clasificación JEL: O17, E51. 


\section{Introduction}

Money always played significant role in the establishment and existence of any state ensuring the stable development of its social, political and economical systems. Money and its use for the entire existence of our civilization have been occupying an importance place in the life of virtually every player from a person to a state. However, there is still no unanimous perception of money and their role in society. The latest events in the world that are connected with the intensification of globalizing socio-political and economical processes let us say that under current conditions the use of money has been transforming itself and reaching beyond its traditional functions. The rapid growth of the shadow economy in the world and at the country level, the spread of crime in the movement of cash flows both inside and outside the country, as well as increasing the risk of terrorist financing by cash of illegal origin, necessitates a thorough study of the means and instruments used listed processes. The objective of the research is to prove the validity of the provision that at the present stage of development of socio-economic and political interaction in society, cash is used by key actors not only as an economic instrument, but also as a tool for communication, propaganda, and legalization of proceeds of crime. Authors consider cash as a tool to promote the history of the country and its achievements over a long period.

\section{Literature Review}

Historically money has always been treated ambiguously. Absolutely negative attitude towards money co-existed with its worshiping and endowing with mystical powers. As early as in 1st century BC Roman historian Sallustius in his letters to Caesar appealed to him to cancel money (Mashkin, 1948). Later, during the development of utopian Socialism a number of its representatives suggested that the social structure should be changed by means of a money reform, i.e. to get rid of all problems in modern society a non-monetary (in its modern understanding) exchange should be organized. At the current stage of social development some attempts were also undertaken to refuse the use of money. The professional legal literature describes cases where during the period of "war communism" attempts were made to invent another form of economic accounting instead of money. However, they were also unsuccessful. On this occasion Voronova (2003) notes that in the only country in the world, the USSR, from 1917 to 1940, they believed that in the Soviet system of law there was nothing to separate financial law, since the state was going to socialism and money would soon die off. Then, in the late 60's, when the slogan "The current generation of Soviet people will live under communism" prevailed, other scientists came to the conclusion that the money was soon dying. Also, as Hamori (1991) points out, attempts have been made to liquidate money in the history of socialism repeatedly. As an example, he cites Cuba's efforts in 1962-1964 to abandon both economic calculations in industry and budgetary financing. Instead of money, they began to issue certificates that were used to pay for work. But finally history proved the objective economical necessity for the existence of this social phenomenon (saeed et al 2019).

Traditionally, when studying money, Savluk et al. (2011) agree that its essence is complicated and because of that they make a conclusion that the world economical thought is unable to give a clear and complete definition of this notion. When defining the essence of money, almost all researchers start with the functions performed by money, in their opinion. But it is worth mentioning that there is no unilateral understanding of either the number of money functions or their meanings in modern economical studies (ayub et al 2020). The analysis of scientific literature on the issue of money shows that researchers tend to distinguish minimum one (winner of the Nobel price Hayek (1996) believes money performs only one function, i.e. exchange) and up to seven functions (Kosoy, 2002) analyzes seven monetary functions including measure of value, price scale, means of circulation, payment, accumulation, means of value storage and the function of global prices). Teletov et al. (2019) consider approaches in the framework of advertising tools and how it is possible to explain the essence of cash through marketing. 
At the same time most researchers tend to distinguish five functions of money, namely the following: measure of value, means of circulation, means of payment, means of accumulation and the function of global prices. We certainly agree that money is an economic phenomenon, but looking at their current state and the peculiarities of circulation, it is difficult to argue that money is a multifaceted object whose nature cannot be uniquely determined and is related to some one sphere. In its turn this allows stating that money as a complex socio-cultural and economical phenomenon keeps getting more complicated under modern conditions.

There is a vivid discussion in economical literature concerning the information function being performed by money. Some authors (Evtukh, 2006) state that using the information function of money commercial players can not only estimate the real condition of the state economy but also forecast its economical and social development, plan the activity of an enterprise or individual under the conditions of ambiguity. Some authors, in particular, the Nobel Prize winners Hayek (1996), Friedman and Schwartz (1963), support the idea that the information function is performed not by money but prices, and the system of prices is a carrier of market information. So at the present stage of human civilization development cash money in its traditional manifestation and objectification form is being used by different players, in particular, states as a political instrument, in particular as a propaganda tool. Traditional money and objectification means the circulation of money in the form of banknotes and coins approved by an authorized state body.

A systematic analysis of the scientific works shows that the study of the essence, development and improvement of propaganda, features of its use, is represented by five main approaches: ideological (Taylor, 2003; Klanfer, 1939), psychological (Chakotin, 1940; Farago, 1958; Janowitz, 1958; White, 1958) culturological (Ross, 2002), communicative (Lasswell, 1948; Schramm, 1997) and technological (Rosenberg, 2003).

In the most generalized view propaganda is a concept that is objectified in the system of activity designed to spread knowledge, values, information with view of forming certain opinions, beliefs, emotional states and influencing the behaviour of people. This activity includes all possible tools, methods and means of rendering information, whose use helps the transmitter to reach its objective. At the same time, propaganda as a system activity differs significantly from information messages in terms of audience size, time of realization, end goal, quality of information reliability, number of carriers, and can have extremely devastating consequences for society. Soliman et al. (2021) note the need to take into account the relationship between the level of state regulation of education and the effectiveness of sustainable development strategies in the analysis of propaganda.

In the current context of the rapid penetration of digital technologies in all areas of activity, the impact of these processes on cash flow should be explored. In particular, Taraniuk et al. (2016) emphasize the importance of developing and implementing a comprehensive risk management system to increase the economic efficiency of the economic activity of enterprises in carrying out radical transformational changes. Bilan (2019) note that digitization and virtualization in the age of Industry 4.0 correct the nature of finance and interaction between market participants.

The role of cash in the processes of shadowing of the economy is investigated on the basis of bibliometric analysis of the spread of the concept of "shadowing of the economy" in scientific articles indexed by the Web of Science science metric database (using the software product VOSviewer v.1.6.10). In 2010-2018, 1686 articles were found in the Web of Science database on the keywords "economy shadowing" and "cash". In general, the results of the analysis showed that the most actively investigated these issues in the period from 2010 to 2012. In recent years, complex studies of these issues have been of a solitary nature (saleem et al 2017). The issues shadowing of the economy with the participation of cash were most active investigated in the USA, Great Britain, Germany, Spain, Austria, Romania (Fig. 1).

Visualization of the imposition of terms according to the chronology of their occurrence, allowed to identify the most authoritative researchers and to identify six clusters of research teams that most influenced the study of the role of cash in shadow operations (Fig. 2). 
Figure 1 Study of shadow economy by geographical feature

its vosviewer

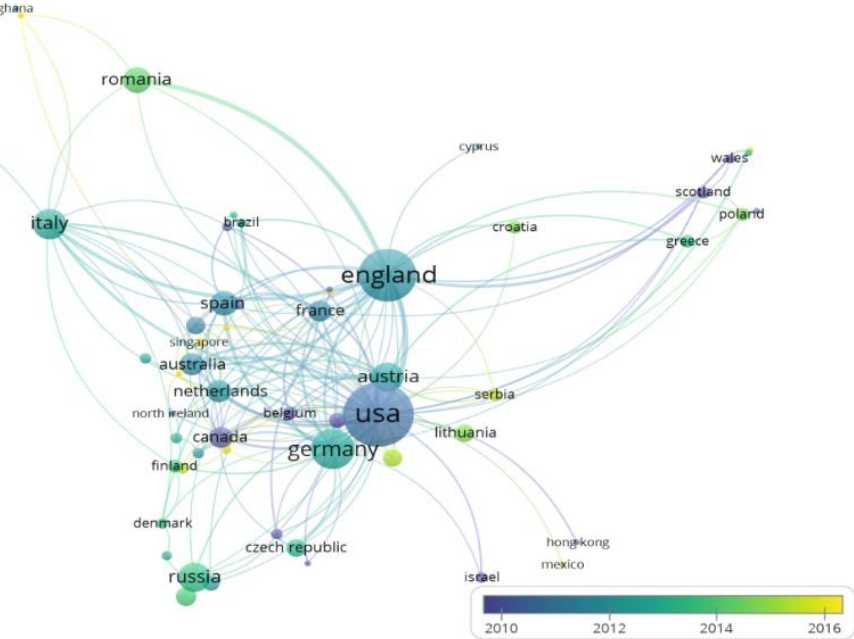

Source: compiled by the authors based on Web of Science Data

Figure 2 Network visualization of terms used

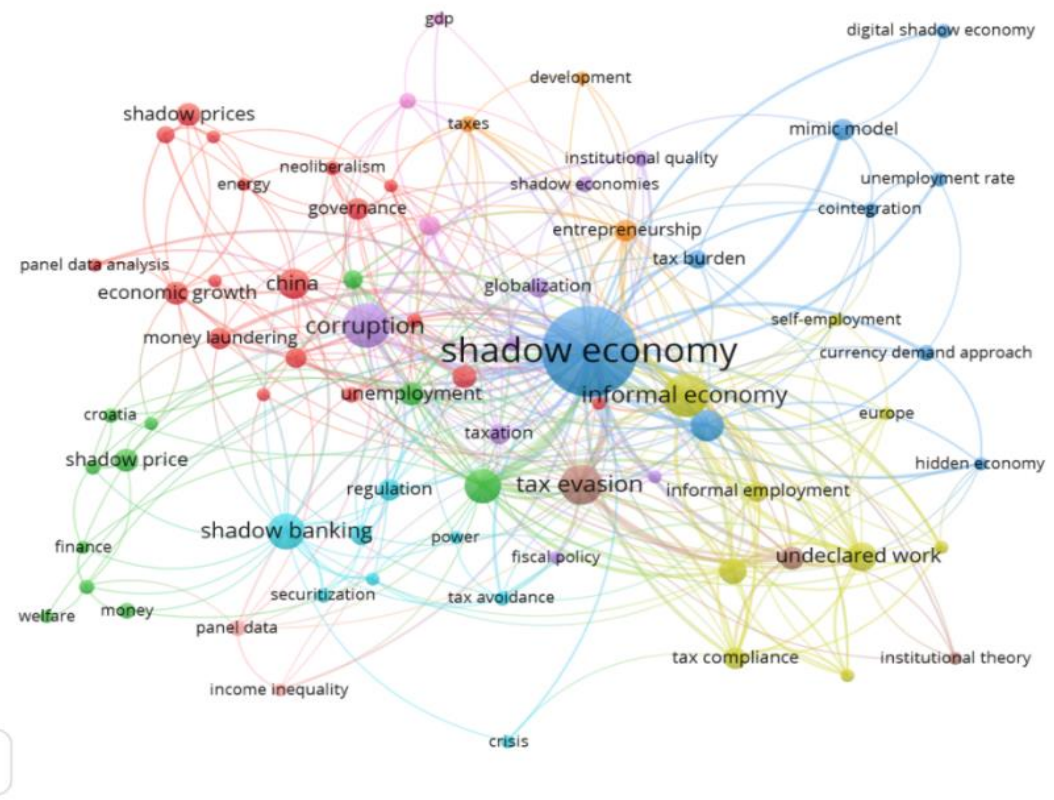

\& vosviewer

Source: compiled by the authors based on Web of Science Data

To determine the structural and functional environment of currency functioning outside the official sector of the economy, as well as to identify relationships with other areas of research, we analyzed the frequency of use of keyword combinations in scientific works (with a frequency of $\geq 7$ mentions of a key term per article) and their network visualization.

It were identified 77 key connecting terms. The closest was the relationship between the shadow economy and corruption, tax evasion, shadow banking, undeclared work, shadow price, money laundering.

The closest was the relationship between the shadow economy and corruption, tax evasion, shadow banking, undeclared work, shadow price, money laundering. 


\section{Data and Methodology}

The analysis of the existing methods for assessing the level of income shadowing (Tanzi (1983), Turchinov (1995), Leonov et al. (2014), Tiutiunyk et al. (2019)) which differ in various quantitative and qualitative indicators, shows that monetary methods are most common for assessing the scope of income shadowing in developed market economies. The use of such methods is based on the premise that shadow schemes are realized using cash only.

In order to test the author's hypothesis about the existence of a link between the level of shadowing of the economy and the amount of cash outside the bank, we will analyze the nature and strength of the link between the level of shadowing in the country and the following indicators: monetary aggregate (MO), monetary base to broad money ratio (MB), Broad Money (BM), Gross Domestic Product (GDP). The subject of study will be 7 European countries (Poland, Belarus, Bulgaria, Georgia, Switzerland, USA and Ukraine), which are characterized by different levels of economic development and volume of shadow financial transactions. The connection is checked for three types: linear, nonlinear, and asymmetric.

In the first step, we test the hypothesis that there is a linear relationship between the resultant and the defined factor traits. The basic model has the following form:

$$
\log \left(\mathrm{SE}_{\mathrm{i}, \mathrm{t}}\right)=\alpha_{\mathrm{i}}+\beta_{0}+\beta_{1} \log \left(\mathrm{SE}_{\mathrm{i}, \mathrm{t}-1}\right)+\beta_{2} \log \left(\mathrm{D}_{\mathrm{n}, \mathrm{i}, \mathrm{t}-1}\right)+\beta_{3} \mathrm{t}+\epsilon_{\mathrm{i}, \mathrm{t}}
$$

where SEi, $t$ - the level of the shadow economy in the country $i$ for the period $t$;

$D_{n, i, t-1}-n$-driver of the shadow economy in the country i for the period $t-1$;

Quite often the relationship between the indicators of a country's economic development is nonlinear and can be described by the following equation:

$$
\mathrm{SE}_{\mathrm{i}, \mathrm{t}}=\alpha_{\mathrm{i}}+\beta_{0}+\beta_{1} \mathrm{D}_{\mathrm{i}, \mathrm{t}-1}+\beta_{2} \mathrm{D}_{\mathrm{n}, \mathrm{i}, \mathrm{t}-1}^{2}+\beta_{3} \mathrm{SE}_{\mathrm{i}, \mathrm{t}-1}+\beta_{4} \mathrm{t}+\epsilon_{\mathrm{i}, \mathrm{t}}
$$

The asymmetric relationship between the indicators can be described by the following equation:

$$
\log \left(\mathrm{SE}_{\mathrm{i}, \mathrm{t}}\right)=\alpha_{\mathrm{i}}+\beta_{0}+\beta_{1} \log \left(\mathrm{D}_{\mathrm{n}, \mathrm{i}, \mathrm{t}-1}\right)+\beta_{2} \log \left(\mathrm{D}_{\mathrm{n}, \mathrm{i}, \mathrm{t}-1}\right) \times \mathrm{N}_{\mathrm{t}-1}+\beta_{2} \log \left(\mathrm{SE}_{\mathrm{n}, \mathrm{i}, \mathrm{t}-1}\right)+\beta_{4} \mathrm{t}+\epsilon_{\mathrm{i}, \mathrm{t}}
$$

where Nt-1- fictitious variable. If the determinant value increases in the period $t-1$, the fictitious variable is 1 , if it decreases -0 .

\section{Results}

The results of the hypothesis test regarding the linear relationship between the indicators (table 1), let us to conclude to conclude that there is a negative and statistically significant linear relationship between the level of shadow economy and GDP for all countries. At the same time, it is a positive relationship for such factors as MO (Ukraine, Poland, Belarus, Georgia, Japan), MB (except Bulgaria) and BM (Ukraine, Poland, Bulgaria, Switzerland, USA). At the same time, there is considerable scope in the levels of dependency between indicators. For example, an increase in GPD by $1 \%$ leads to an decrease in the logarithmic value of the shadow economy by $14.5 \%$ in developing countries and only by $5 \%$ in Georgia.

Based on the calculations, we can conclude that there is a non-linear relationship between the level of shadow economy and the indicator MO - for Bulgaria and Switzerland, MV - for Bulgaria and broad money for Belarus, Georgia, Japan. For the rest of the countries, the link between the resultant and factor indicators has not been confirmed. 
Table 1 Results of the hypothesis verification regarding the linear relationship between drivers and shadow economy

\begin{tabular}{|c|c|c|c|c|}
\hline Country & $\mathrm{MO}$ & $\mathrm{MB}$ & $\mathrm{BM}$ & GDP \\
\hline Ukraine & $0.1587^{\star}$ & $0.1658^{*}$ & $0.2354^{*}$ & $-0.1458^{*}$ \\
\hline Poland & $0.1256^{*}$ & $0.1524^{*}$ & $0.1589^{*}$ & $-0.0741^{*}$ \\
\hline Belarus & $0.1358^{*}$ & $0.1368^{*}$ & 0.4752 & $-0.0681^{*}$ \\
\hline Bulgaria & 0.1407 & 0.0882 & $0.3658^{*}$ & $-0.1214^{*}$ \\
\hline Georgia & $0.1301^{*}$ & $0.0985^{\star}$ & 0.1224 & $-0.0547^{*}$ \\
\hline Switzerland & 0.0185 & $0.1658^{*}$ & $0.1358^{*}$ & $-0.1146^{*}$ \\
\hline Japan & $0.0952^{*}$ & $0.1296^{*}$ & 0.2547 & $-0.0342^{*}$ \\
\hline USA & 0.1228 & $0.0713^{*}$ & $0.3852^{*}$ & $-0.0901^{*}$ \\
\hline
\end{tabular}

Source: compiled by the authors

Table 2 Results of the hypothesis verification regarding the linear relationship between drivers and shadow economy

\begin{tabular}{|l|l|l|l|l|}
\hline Country & M0 & MB & BM & GDP \\
\hline Ukraine & 0,1802 & 0,1903 & 0,3261 & $-0,2093$ \\
\hline Poland & 0,1426 & 0,1749 & 0,2201 & $-0,1212$ \\
\hline Belarus & 0,1542 & 0,1570 & $0,3732^{*}$ & $-0,1250$ \\
\hline Bulgaria & $0,1598^{*}$ & $0,1012^{*}$ & 0,2873 & $-0,1500$ \\
\hline Georgia & 0,1477 & 0,1130 & $0,1696^{*}$ & $-0,1085$ \\
\hline Switzerland & $0,0210^{*}$ & 0,1853 & 0,1881 & $-0,1645$ \\
\hline Japan & 0,1081 & 0,1487 & $0,3529^{*}$ & $-0,0936$ \\
\hline USA & 0,1395 & 0,1103 & 0,5337 & $-0,1383$ \\
\hline
\end{tabular}

Source: compiled by the authors

The results of the calculations did not confirm the existence of an asymmetric relationship between the analyzed indicators (Table 3).

Table 3 Results of the hypothesis verification regarding the asymmetric relationship between drivers and shadow economy

\begin{tabular}{|l|l|l|l|l|}
\hline Country & M0 & MB & BM & GDP \\
\hline Ukraine & 0.1254 & 0.0254 & 0.1254 & 0.3564 \\
\hline Poland & 0.2514 & 0.0541 & 0.1035 & 0.1455 \\
\hline Belarus & 0.0901 & 0.0125 & 0.1135 & 0.2145 \\
\hline Bulgaria & 0.1354 & 0.0678 & 0.1578 & 0.0898 \\
\hline Georgia & 0.1025 & 0.1254 & 0.0980 & 0.0908 \\
\hline Switzerland & 0.0987 & 0.1125 & 0.1306 & 0.1021 \\
\hline Japan & 0.1542 & 0.0957 & 0.0023 & 0.0988 \\
\hline USA & 0.1325 & 0.0875 & 0.0214 & 0.0887 \\
\hline
\end{tabular}

Source: compiled by the authors

\section{Discussion}

In general, taking into consideration the present state and types of money circulation, we agree that money performs the information function in the economic mechanism of state functioning and we also share the idea Phillips (1997) that money can be considered to be an economical mirror, but 
we would like to draw readers' attention to another aspect of the information function of money, namely keeping the population informed about socio-political events in the society.

Money as a type of mass media has been in use practically from its coming into existence. All sovereigns that possessed power and made coins tried to render the information to their subordinates about this power by coining their own portraits or emblems of city-states.

There were several reasons explaining this fact, including: a) money was coined once (at least, rulers tended to think so) and the information it carried was the most important and "eternal"; b) money was used all over the territory of the state and sometimes beyond its borders, which enlarged the territory and audience to be informed; c) money had an official character, which made their information official and authentic.

The above-mentioned reasons to use money with view of rendering information that is necessary for the issuer remain functional at the current state of our social development too.

Certainly the information conveyed through money did not have absolute completeness, but it could be communicated to practically the whole population, since money was used by all sections of the population, both rich and poor. It should be emphasized that the information that was coined on the money and communicated to the population was one-sided. Its recipients were unable to question it and were treated equally as it was reported by the money issuer. This feature, in terms of propaganda, is highly important because even when the population disagreed with the information thus obtained, it could not raise any objections. Instead, the intensive use of money with the information on it, contributed to its constant perception and memorization.

The most vivid illustration of this trend can be received by analyzing the images on banknotes in such post-Soviet states as the Republic of Belarus (table 4), Georgia (table 5) and Ukraine (table 6).

Table 4 Description of images on the banknotes of the Republic of Belarus

\begin{tabular}{|c|c|c|}
\hline $\begin{array}{l}\text { Nominal } \\
\text { value }\end{array}$ & Image on the obverse & Image on the reverse \\
\hline 5 rubles & $\begin{array}{l}\text { Belaya Vezha in Kaminets, Brest } \\
\text { Region }\end{array}$ & $\begin{array}{l}\text { Collage (a piece of a leather belt, a wooden wheel, } \\
\text { wooden citadel Berestya) }\end{array}$ \\
\hline 10 rubles & $\begin{array}{l}\text { Transfiguration Church in } \\
\text { Polotsk, Vitebsk Region }\end{array}$ & $\begin{array}{l}\text { Collage (sign of FranciscusScorina, cross of } \\
\text { Euphrosyne of Polotsk, a piece of ornamentation) }\end{array}$ \\
\hline 20 rubles & $\begin{array}{l}\text { Rumyantsev-Paskevich } \\
\text { Residence in Homyel }\end{array}$ & $\begin{array}{l}\text { Collage (a bell, the Gospel Book of Turov, ancient } \\
\text { town of Turov, pieces of carvings) }\end{array}$ \\
\hline 50 rubles & Mir Castle in Mir, Grodno Region & $\begin{array}{l}\text { Collage (a lyre, laurel branches, a feather, paper, a } \\
\text { musical staff) }\end{array}$ \\
\hline 100 rubles & $\begin{array}{l}\text { Radziwill castle in Nesvizh, Minsk } \\
\text { Region }\end{array}$ & $\begin{array}{l}\text { Collage (a violin, a tambourine, zhaleyka wind } \\
\text { instrument, and symbols of folk holidays: a Christmas } \\
\text { star, a goat, "Batleyka" theatre) }\end{array}$ \\
\hline 200 rubles & $\begin{array}{l}\text { Maslenikov Regional Museum of } \\
\text { Art in Mogilev }\end{array}$ & $\begin{array}{l}\text { Collage (a golden key and a seal of Mogilev, tiles, a } \\
\text { piece of forged lattice) }\end{array}$ \\
\hline 500 rubles & $\begin{array}{l}\text { The National Library of Belarus in } \\
\text { Minsk }\end{array}$ & $\begin{array}{l}\text { Collage (a feather, an inkwell, book covers, a fern } \\
\text { leaf) }\end{array}$ \\
\hline
\end{tabular}


Table 5 Description of images on the banknotes of Georgia

\begin{tabular}{|c|c|c|}
\hline $\begin{array}{l}\text { Nominal } \\
\text { value }\end{array}$ & Image on the obverse & Image on the reverse \\
\hline 1 lari & $\begin{array}{c}\text { Niko Pirosmani, an outstanding Georgian } \\
\text { painter of the 20th century }\end{array}$ & Panorama of Tbilisi, the capital of Georgia \\
\hline 2 laris & $\begin{array}{l}\text { ZachariaPaliashvili, a Georgian composer, } \\
\text { teacher, public figure }\end{array}$ & $\begin{array}{c}\text { Building of the Tbilisi ZachariaPaliashvili } \\
\text { Opera and Ballet State Theatre founded in } \\
1851\end{array}$ \\
\hline 5 laris & $\begin{array}{l}\text { IvaneJavakhishvili, a Georgian historian, } \\
\text { member of the Academy of Sciences of the } \\
\text { USSR (1939), one of the founders of the } \\
\text { Tbilisi University named after him }\end{array}$ & $\begin{array}{l}\text { IvaneJavakhishvili Tbilisi State University, the } \\
\text { oldest and the most prominent educational } \\
\text { institution in Georgia, science and cultural } \\
\text { centre. It was founded in February } 1918 \\
\text { (banknote of 1995). A painting by Niko } \\
\text { Pirosmani (banknote of 2006, 2016) }\end{array}$ \\
\hline 10 laris & $\begin{array}{l}\text { AkakiTsereteli, a prominent Georgian poet } \\
\text { and public figure }\end{array}$ & Mother's portrait by David Kakabadze \\
\hline 20 laris & $\begin{array}{c}\text { Ilia Chavchavadze, a Georgian writer and } \\
\text { public figure }\end{array}$ & Sculpture of VakhtangGorgasali \\
\hline 50 laris & Queen Tamar from Bagrationi dynasty & $\begin{array}{l}\text { Astrological sign of "Sagittarius" from the } \\
\text { Georgian miniature manuscript of the 12th } \\
\text { century }\end{array}$ \\
\hline 100 laris & $\begin{array}{c}\text { Shota Rustaveli, a 12-century Georgian } \\
\text { poet, one of the outstanding representatives } \\
\text { of medieval literature }\end{array}$ & $\begin{array}{c}\text { 7th century bas-relief of biblical plot "Daniel in } \\
\text { the Den of Lions" from Martvili Cathedral of } \\
\text { Assumption of the Virgin Mary (banknote of } \\
1995 \text { ) } \\
\text { The National Theatre of Opera and Ballet } \\
\text { (banknote of 2006, 2016) }\end{array}$ \\
\hline 200 laris & $\begin{array}{c}\text { Kakutsa Cholokashvili (1888-1930), a } \\
\text { Georgian prince, military leader, one of the } \\
\text { leaders of August } 1924 \text { rebellion, a national } \\
\text { hero of modern Georgia }\end{array}$ & $\begin{array}{c}\text { Panorama of Sukhumi, city on the eastern } \\
\text { coast of the Black Sea, the capital and the } \\
\text { biggest city in Abkhazia, which is considered } \\
\text { to be an autonomy within Georgia by most } \\
\text { countries of the world }\end{array}$ \\
\hline
\end{tabular}

Source: compiled by the authors based on data of the National Bank Georgian

The following peculiarities should be pointed out in the modern practice of using money to render information. Money is used in the most intense way at the initial stage of its issuer or when it is necessary to highlight a certain event. In this case, by the term "issuer" we mean sovereign states or state entities that, according to their current legislation, have the right to issue banknotes and coins.

Most states coinage their national symbols, important places, outstanding institutions or portraits of national heroes, researchers or figures of culture on their money. It can be explained by the fact that, when appearing on the political map of the world, each state tries to identify itself somehow and show its differences from other countries if it has emerged on a vacant territory, or prove its achievements and success of their own people or dominant ethnic group if this country has come into being after disintegration of a previous state or separation from another one. The same trend could be followed by analyzing the banknotes of the countries that joined the European Union before the introduction in 2002 of the cash euro - official currency of the European Union.

This trend is also characteristic of the countries of North and South America. In particular, the USA banknotes depict portraits of the United States presidents who have made a significant contribution to the formation of the state, the banknotes of Canada also depict political figures (Prime Ministers of Canada and Queen Elizabeth II) who also made a significant contribution to becoming Canada a state.

The Brazilian banknotes depict the Republic symbol and representatives of the flora and fauna with a zone of distribution in the territory of this state, the Mexican banknotes depict national heroes, political and cultural figures and architectural monuments in the territory of the state. 
Table 6 Description of images on the banknotes of Ukraine

\begin{tabular}{|c|c|c|}
\hline $\begin{array}{l}\text { Nominal } \\
\text { value }\end{array}$ & Image on the obverse & Image on the reverse \\
\hline 1 hryvnia & \begin{tabular}{|c|} 
Volodymyr the Great, Prince of the Rus from \\
Rurik dynasty. The Grand Prince of Kyiv (979- \\
1015), ruler and christianizer of KievanRus
\end{tabular} & The city of Volodymyr (Kyiv) \\
\hline 2 hryven & \begin{tabular}{|} 
Yaroslav the Wise, Prince of the Rus from \\
Rurik dynasty. The Grand Prince of Kyiv (1015- \\
1018, 1019-1054)
\end{tabular} & $\begin{array}{l}\text { The Saint Sophia's Cathedral in Kyiv, a } \\
\text { monument of Ukrainian architecture and } \\
\text { monumental painting from 11-18th centuries, one } \\
\text { of rare buildings kept from the times of Kievan } \\
\text { Rus. One of the most important sacred places for } \\
\text { Christianity in Eastern Europe, the historical } \\
\text { centre of Kyiv metropole }\end{array}$ \\
\hline 5 hryven & $\begin{array}{c}\text { Bohdan Khmelnytsky, Ukrainian military } \\
\text { political and state figure. Hetman of Ukraine } \\
(1648-1657)\end{array}$ & $\begin{array}{l}\text { A church in the village of Subotiv, Chyhyryn } \\
\text { district, Cherkasy Oblast, built in } 1653 \text { (1656) by } \\
\text { order of Hetman Bohdan Khmelnytsky as his } \\
\text { family vault }\end{array}$ \\
\hline 10 hryven & $\begin{array}{l}\text { Ivan Mazepa, Ukrainian military political and } \\
\text { state figure. Hetman of Ukraine (1687-1704) } \\
\text { and (1704-1709) }\end{array}$ & $\begin{array}{c}\text { Kyivo-PecherskaLavra } \\
\text { Orthodox monastery complex in Kiev, Ukraine. } \\
\text { One of the biggest Christian centers on eastern } \\
\text { Europe. A prominent monument of history and } \\
\text { architecture }\end{array}$ \\
\hline 50 hryven & $\begin{array}{c}\text { MykhailoHrushevskyi, a Ukrainian historian, } \\
\text { political and public figure. The Head of the } \\
\text { Central Rada in the Ukrainian People's } \\
\text { Republic (1917-1918). }\end{array}$ & The Central Rada building (Kyiv) \\
\hline 100 hryven & $\begin{array}{l}\text { Taras Shevchenko, a Ukrainian poet, writer, } \\
\text { play-write, painter, public and political figure. } \\
\text { National hero and symbol of Ukraine }\end{array}$ & Dnipro and blind bandurist with a guide \\
\hline 200 hryven & $\begin{array}{c}\text { LesyaUkrainka } \\
\text { Ukrainian writer, translator, cultural figure. }\end{array}$ & Lubart Castle (Lutsk) and flying stork \\
\hline 500 hryven & \begin{tabular}{|c|}
$\begin{array}{c}\text { HryhoriiSkovoroda, an outstanding Ukrainian } \\
\text { philosopher, mystic, theologian, poet, teacher, } \\
\text { perhaps the composer of liturgical music }\end{array}$ \\
\end{tabular} & $\begin{array}{c}\text { The Kyiv Mohyla Academy, the highest } \\
\text { educational institution in Ukraine, founded in } \\
1615\end{array}$ \\
\hline $\begin{array}{l}1000 \\
\text { hryven }\end{array}$ & \begin{tabular}{|} 
Vladimir Vernadsky \\
Ukrainian scientist and philosopher. Naturalist, \\
founder of geochemistry, biogeochemistry and \\
radiogeology, doctrine of the biosphere, \\
cosmism. Academician of the St. Petersburg \\
Academy of Sciences (since 1912), professor \\
at Moscow University.
\end{tabular} & The national Academy of Sciences of Ukraine \\
\hline
\end{tabular}

Source: compiled by the authors based on data of the National Bank of Ukraine

Given the above, we can say that the information provided by the state through a specific design of banknotes is great political importance for its formation and development. Also, virtually all countries in the world use this kind of money as commemorative coins to raise public awareness of a particular event, or to convey information about a state's attitude to it. For the first time in modern history, commemorative coins were issued by the United States Mint in 1892 to commemorate the opening of Christopher Columbus of America, which was celebrated at the World Exposition in Chicago in 1893. Fifty cent silver coins were being sold for a dollar. In view of such a gain, the practice of producing commemorative coins in the United States continued in the following years and was subsequently adopted by other states. The design of such coins clearly indicated a particular event and its date. The vast majority of coins in this category serve solely as collectibles, but some states issue commemorative coins for regular circulation. Today, virtually every state, celebrating a particular event, issues commemorative coins.

Investigating the effectiveness of passing information to the population should take into account the stability of the currency and the prevalence of notes in circulation. The currency stability indicator makes it possible to determine the need to change the design of the denomination, and accordingly the information on it. The banknote prevalence rate allows you to determine which banknote is the most common banknote and, accordingly, which banknote is most commonly used. An appropriate 
indicator enables the state to select the most common denomination for the most important information. As an example, let us look at the prevalence of banknotes in Ukraine and the importance of graphical information displayed on them to determine the socio-cultural landmarks of Ukraine's development. For analysis, we obtained statistical data from the official website of the National Bank of Ukraine on the structure of cash circulation of the hryvnia as of January 1, 2020 (Table 7).

The analysis of the table above proves that the most widely used banknotes are those with the nominal value of 1, 100, 200 and 500 hryven. Analysis of images on banknotes of cash of Ukraine allows to draw the relevant conclusions. So, Volodymyr the Great (St. Volodymyr), is shown for 1 $\mathrm{UAH}$, is one of the most prominent political figures in Ukrainian history. He was the Grand Prince of Kievan Rus, he is also known for christening Kievan Rus, in the territory of which modern Ukraine now exists as an independent state. Volodymyr the Great is canonized by the Catholic and Orthodox Churches as Equal to the Apostles. With the help of this image on the banknote with the least nominal value Ukraine positions itself as a successor of Kievan Rus and the state from whose territory the Christianization of the Slavic peoples began and Christianity as one of the global religions got spread.

Table 7 Structure of cash circulation of Ukraine (on 01.01.2020)

\begin{tabular}{|l|c|c|c|c|c|}
\hline \multicolumn{3}{|c|}{ Banknote nominal value } & \multicolumn{3}{c|}{ Coin nominal value } \\
\hline nominal value & $\begin{array}{c}\text { Amount in } \\
\text { circulation } \\
\text { (millions of } \\
\text { pieces) }\end{array}$ & $\begin{array}{c}\% \text { of total } \\
\text { amount of } \\
\text { cash in } \\
\text { circulation }\end{array}$ & $\begin{array}{c}\text { Coin } \\
\text { nominal } \\
\text { value }\end{array}$ & $\begin{array}{c}\text { Amount in } \\
\text { circulation } \\
\text { (millions of } \\
\text { pieces) }\end{array}$ & $\begin{array}{c}\% \text { of total } \\
\text { amount of coins } \\
\text { in circulation }\end{array}$ \\
\hline $1 \mathrm{UAH}$ & 491,2 & $16,74 \%$ & 1 kopeck & 2435,2 & $18,42 \%$ \\
\hline $2 \mathrm{UAH}$ & 202,0 & $6,88 \%$ & 2 kopeck & 1395,4 & $10,45 \%$ \\
\hline $5 \mathrm{UAH}$ & 259,8 & $8,85 \%$ & 5 kopeck & 1858,4 & $13,92 \%$ \\
\hline $10 \mathrm{UAH}$ & 186,3 & $6,35 \%$ & 10 kopeck & 3857,2 & $28,81 \%$ \\
\hline $20 \mathrm{UAH}$ & 134,4 & $4,58 \%$ & 25 kopeck & 1706,2 & $12,78 \%$ \\
\hline $50 \mathrm{UAH}$ & 168,4 & $5,74 \%$ & 50 kopeck & 1262,0 & $9,45 \%$ \\
\hline $100 \mathrm{UAH}$ & 337,4 & $11,49 \%$ & $1 \mathrm{UAH}$ & 669,4 & $5,01 \%$ \\
\hline $200 \mathrm{UAH}$ & 687,5 & $23,43 \%$ & $2 \mathrm{UAH}$ & 167,0 & $1,25 \%$ \\
\hline $500 \mathrm{UAH}$ & 464,0 & $15,81 \%$ & $5 \mathrm{UAH}$ & 0,8 & $0,02 \%$ \\
\hline $1000 \mathrm{UAH}$ & 3,9 & $0,13 \%$ & & & \\
\hline
\end{tabular}

Source: compiled by the authors based on data of the National Bank of Ukraine

The banknotes with the nominal value of 100, 200 and 500 UAH depict the images of such national Ukrainian figures as Taras Shevchenko, Lesya Ukrainka and Hryhorii Skovoroda. These historical figures are the most well-known in the world and in their lifetime made a significant contribution to the establishment and distinguishing of the Ukrainian nation among other Slavic peoples.

The high share of the cash component in the structure of the total money supply in circulation makes it possible to legalize illegal income obtained by criminal means.

The use of cash as the main facilitator (a tool that facilitates the achievement of the goal) in the cycle of laundering of the proceeds of crime is a problematic issue that is monitored at the level of both highly developed countries and developing countries. Over the past decade, cross-border cash flows have been the subject of meticulous analysis by the FATF, Europol, the European Commission, and Money Val.

During the analysis of the risks of using cash, based on research by European Police Office (2015), the State Financial Monitoring Service notes that Switzerland is currently the most vulnerable country in terms of incoming illegal cash flows, primarily from third world countries. China has been defined as the country that is the most common final destination for cash transfers from EU countries, and Turkey has been defined as a country that plays a major role in the transit movement of cash from Europe to the Middle East. Nigeria has been defined as the primary country of origin of suspicious cash flows to EU countries. Ukraine is positioned as a country where money couriers declare the amounts of cash that they usually import into the EU openly and fully, whereas competent authorities of the EU countries have suspicions about the legality of the source of origin of the cash transported in significant physical volumes across the borders of EU member states by Ukrainians. 
Despite the steady spread of non-cash payment technologies, the decrease in cash payments in the world is occurring slowly. For example, according to the Future of Payments 2016 study, the global retail payment transaction market currently consists of the use of payment cards $(9,1 \%)$, transfers and direct payments $(4,6 \%)$, checks $(1,2 \%)$ and cash $(85 \%)$. As of January 1,2020 , the cash in circulation in Ukraine amounts to UAH 425 billion, which is $6,2 \%$ more than a year earlier (UAH 400,1 billion as of January 1, 2019).

Money Val (Committee of Experts on the Evaluation of Anti-Money Laundering Measures and the Financing of Terrorism) identifies 7 zones of national risk for Ukraine, which should be minimized by the regulatory and banking policy, in particular: corruption, illegal economic activities (fictitious enterprises, fraud, tax evasion), the growth of organized crime, conversion centers, large amounts of cash, the shadow economy, the risk of financing terrorism, including that with the use of non-profit organizations.

It has been found that, when mainly cash is used in shadow transactions, the demand for cash in the informal sector increases. Therefore, there is a direct correlation - the more cash turnover in the economy, the larger the informal sector of the economy.

The analysis of the structure of the volume of identified fraudulent operations, conducted by the Ministry of Finance of Ukraine for 2017-2018, indicates that fictitious transit operations amount to 22,64 billion UAH., illegal cash withdrawal - 9,66 billion UAH., while the illegal withdrawal of capital amounts to 0,96 billion UAH.

It should be noted that in the structure of transactions with the use of payment cards during 20142018 (Fig. 4), those that involve receiving cash prevail. But in the first quarter of 2019, the share of non-cash payments on the volume of payment card transactions is already $50 \%$, with eight out of 10 transactions - non-cash.

Figure 4: Dynamics of the volume of operations using payment cards, \%

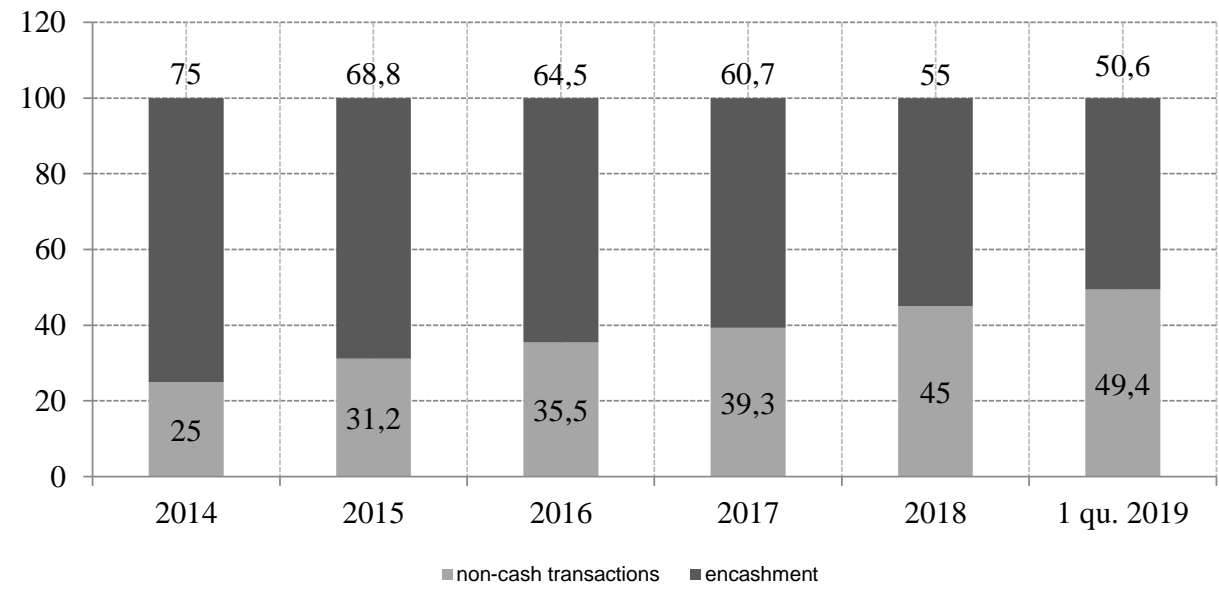

Source: compiled by the authors based on data National Bank of Ukraine

Today, there is a lack of information about the amount of cash used to achieve both legal and illegal goals. However, the use of cash remains the main reason for suspicions about the financial operations carried out in the financial and economic systems of both the EU and Ukraine. Illegal actions related to the conversion of funds into cash have a number of negative consequences that have a destructive effect on the country's monetary system and violate its stability.

Causes of illegal conversion of funds into cash in Ukraine include: execution of illegal activities; creation of a material basis for the functioning of a criminal business: human and drug trafficking and the like; transactions carried out by business entities with use of cash with the purpose of evading mandatory payments to the budget.

The conversion of funds into cash within the schemes of legalization (laundering) of the proceeds of crime is also due to the need for criminals to achieve certain goals, such as: conceal the traces of 
the origin of income received from illegal sources; conceal the individuals who received (receive) illegal income and those initiating the laundering process itself; provide convenient and prompt access to funds received from illegal sources; create the conditions for safe and comfortable use of funds received from illegal sources; create the conditions for the safe investment in a legal business.

It is well known that the use of cash by criminals as the most liquid type of an asset is the initial stage in the cycle of money laundering, preceding the "placement" stage, where criminals try to minimize the risks associated with possible confiscation of non-cash funds. This stage is typical when non-cash funds are converted into cash in the process of embezzling budget funds, using electronic money, and so on. From then on, cash can be legalized using other schemes and used to increase shadow assets, bribe officials at different levels, etc. In addition, conversion of non-cash funds into cash is also used at the last stage of laundering, when the already legalized money is converted into cash, since it is considered the most liquid.

To implement the schemes for the legalization (laundering) of the proceeds of crime, the so-called "breaking the chain" operations are used, which are aimed at masking the traces of the illegal origin of income by changing the owners of funds, their physical movement, and by actually withdrawing them in cash.

The ratio of cash (MO) to GDP determines the safety of the money market, the normative value of which should not exceed 4\% (Radziyevsky, 2005). The analysis of the data in Table 8 shows that the ratio of MO to GDP does not correspond to the normative value and exceeds it significantly, during 2012-2014 has a tendency to increase, and only since 2016 shows a downward trend.

The problem of the propensity of the Ukrainian population to use and accumulate cash is caused by the low confidence in the national banking system and the population's low level of financial literacy.

Table 8 Ratio of cash to GDP and indicator of the shadow economy in Ukraine

\begin{tabular}{|c|c|c|c|c|}
\hline Year & $\begin{array}{c}\text { Amount of cash } \\
\text { (M0), UAH million }\end{array}$ & $\begin{array}{c}\text { GDP, } \\
\text { UAH million }\end{array}$ & $\begin{array}{c}\text { M0 to GDP ratio, } \\
\%\end{array}$ & $\begin{array}{c}\text { Integral indicator of the } \\
\text { shadow economy, \% of GDP }\end{array}$ \\
\hline 2010 & 183000 & 1082569 & 17,0 & 38,0 \\
\hline 2011 & 192600 & 1316600 & 14,8 & 34,0 \\
\hline 2012 & 203200 & 1408889 & 14,42 & 34,0 \\
\hline 2013 & 237800 & 1454931 & 16,34 & 35,0 \\
\hline 2014 & 282900 & 1566728 & 18,06 & 43,0 \\
\hline 2015 & 282673 & 1979458 & 14,28 & 35,0 \\
\hline 2016 & 314392 & 2383182 & 13,19 & 32,0 \\
\hline 2017 & 332546 & 2982920 & 11,15 & 30,0 \\
\hline 2018 & 363629 & 3558706 & 10,22 & \\
\hline
\end{tabular}

Source: compiled by the authors based on data National Bank of Ukraine, State Statistics of Ukraine, Ministry for Development of Economy, Trade and Agriculture of Ukraine

Rogoff (2016) believes that cash is not given enough attention in economic research. According to Khvedchuk (2016) large share of the national currency in circulation can also be a problem for the economy.

The analysis of monetary aggregates as of January 2020 shows that the volume of cash amounted to UAH 370,1 billion. In addition, a significant amount of deposits has been formed that can be converted into cash and enter the market - UAH 389,7 billion. The National Bank views such circulation of cash as a risk for the economy, but Ukrainians cannot refuse cash due to the fact that the share of the shadow economy is about $49 \%$ (this indicates the need for a cash market, which is why demand generates supply). Besides, an uncontrolled build-up in the money supply without entering the real sector of the economy will lead to the hyperinflation and destruction of the economy.

The ratio of cash to GDP in different countries is shown at Fig. 5. 
Figure 5 The ratio of cash to GDP

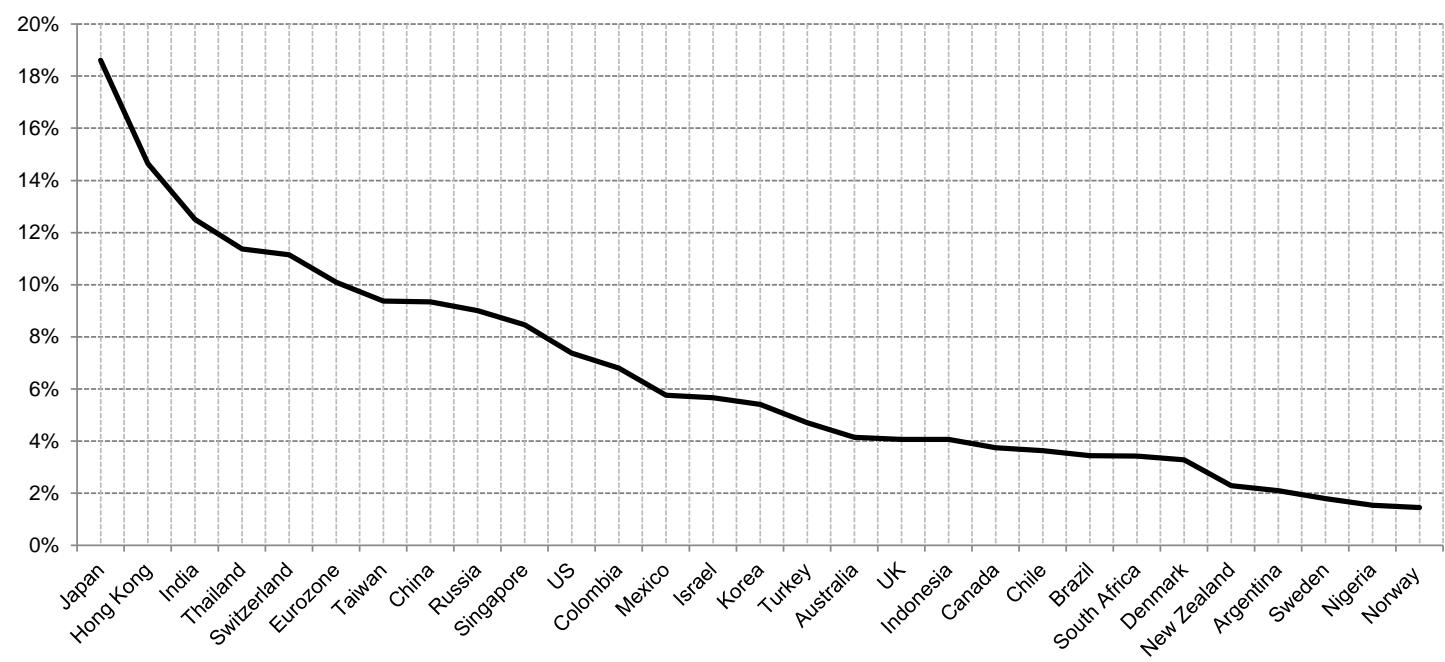

Source: Rogoff K., 2015.

Therefore, any deviations in the amount of cash outside the banks indicate the dynamics of the development or reduction of the shadow sector.

\section{Conclusion}

At the present state of the development of human civilization money is not only a means of exchange that helps facilitating the exchange of goods but it can also be an efficient propaganda tool, i.e. an instrument to render some information necessary for the state and government to create certain political narratives. Money has been found to be one of the most effective propaganda tools with a long exposure time, a large impact area, and a one-sided impact. This should take into account the level of inflation and the tendency of the population to use certain denominations, which will make it possible to predict the frequency of design changes and the prevalence of a denomination.

The calculations conclude that there is a different relationship (in nature and direction) between the level of shadowing of the economy and the indicators of the state of the money market in the country. For most of the indicators analyzed, this relationship is linear. At the same time, the results indicated that there was no asymmetric relationship between the indicators. For Belarus, Bulgaria, Georgia, Switzerland, Japan, a nonlinear relationship between the level of shadowing of the economy and individual indicators of functioning of the country's monetary market has been revealed.

\section{Acknowledgements}

The article was written within the project no. 01170003930 entitled "Econometric modelling of the mechanism of prevention of shadow capital outflows schemes through tax and investment channels in Ukraine" financed by Ministry of Education and Science of Ukraine conducted by Sumy State University in the years 2017-2020.

\section{References}

1. Ayub, N., Irfan, M., Awais, M., Ali, U., Ali, T., Hamdi, M., ... \& Muhammad, F. (2020). Big Data Analytics for Short and Medium-Term Electricity Load Forecasting Using an Al Techniques Ensembler. Energies, 13(19), 5193.

2. Bashynska, I., Baldzhy, M., Ivanchenkova, L., Skliar, L. Nikoliuk, O., Tkachuk, G. (2019). Game Risk Management Methods for Investment Portfolio Optimization. International Journal of Recent 
Technology and Engineering, Volume-8 Issue-2, 2019, pp. 3940-3943 DOI: 10.35940/ijrte.B1729.078219

3. Bilan, Y., Rubanov, P., Vasylieva, T., \& Lyeonov, S. (2019). The Influence of Industry 4.0 on Financial Services: Determinants of Alternative Finance Development. Polish Journal of Management Studies, 19(1), 70-93.

4. Chakotin, S. (1940). The rape of the masses; the psychology of totalitarian political propaganda. New York, Alliance Book Corporation, 310.

5. Evtukh, A. T. (2006). The essence of money through the prism of modern finance. Finance and credit, 6, 16.

6. Farago, L. (1958). Black propaganda: its techniques and requirements. A Psychological Warfare Casebook, Baltimore: Johns Hopkins University Press, 670-672.

7. Friedman, M., Schwartz, A. (1963). Monetary History of the United States 1867-1960. Princeton University Press, 854

8. Hamory, B. (1991). Theory of Socialist Economy. Novosibirsk: Nauka, 23-25.

9. Hayek, F. (1996). Private money. Institute of the National Model of Economics, 114.

10.Janowitz, M. (1958). Language idiom and accent in psychological warfare. A Psychological Warfare Casebook, Baltimore: Johns Hopkins University Press, 609-611.

11.Khvedchuk, K. (2016). Cashless Society and de-Dollarization in Ukraine. What is Missing from Present Discussions?. Visnyk of the National Bank of Ukraine, 238, 6-12.

12.Klanfer, J. (1939). Democracy and propaganda. The Sociological Review, 31(4), 345-452.

13.Kosoy, A. M. (2002). Modern money. Money and credit, 6, 42-54.

14.Lasswell, H. D. (1948). The structure and function of communication in society. The Communication of Ideas, 37-51.

15.Leonov, S., Frolov, S., \& Plastun, V. (2014). Potential of institutional investors and stock market development as an alternative to households' savings allocation in banks. Economic Annals-XXI, 11-12, 65-68.

16.Mashkin, N. A. (1948). History of Ancient Rome. Moscow: OGIZ Publ, 156

17.Phillips, M. (1997). The Seven Laws of Money. Boston: Shambhala, 128.

18. Radziyevsky, O. (2005). Contradictions of dollarization of the Ukrainian economy in the conditions of financial globalization. Economy of Ukraine, 2, 16-23.

19.Rosenberg, A. (2003). Myth of the twentieth century. LLC Svitovid, 585.

20.Rogoff K. (2015). Data for The Curse of Cash. Figure 3.4: Currency-to-GDP ratio.

21.Rogoff, K. (2016). The Curse of Cash. Princeton University Press (Kindle), 296.

22.Ross, Sh. T. (2002). Understanding Propaganda: The Epistemic Merit Model and Its Application to Art. Journal of Aesthetic Education, 36(1), 16-30.

23.Savluk, M. I., Moroz, A. M., Lazepko, I. M. et al. (1997). Hroshi ta kredyt. Kyiv: KNEU, 14-15.

24.Saeed, S., Shaikh, A., Memon, M. A., \& Nizamani, M. A. (2019). Systems Development Life Cycle Test Driven Technique and Defect investigation. University of Sindh Journal of Information and Communication Technology, 3(3), 128-134.

25.Saleem, K., Shahzad, B., Orgun, M. A., Al-Muhtadi, J., Rodrigues, J. J., \& Zakariah, M. (2017). Design and deployment challenges in immersive and wearable technologies. Behaviour \& Information Technology, 36(7), 687-698.

26.Schramm, W. (2011). Carl Hovland: Experiments, attitudes, and communication. The beginnings of communication study in America: A personal memoir by Wilbur Schramm. London: New Delhi, 87105.

27.Soliman, M., Lyulyov, O., Shvindina, H., Figueiredo, R., \& Pimonenko, T. (2021). Scientific output of the European Journal of Tourism Research: A bibliometric overview and visualization. European Journal of Tourism Research, 28, 2801-2801 
28.Tanzi, V. (1983). The underground economy in the United States: annual estimates", IMF Staff Papers, 30(2), 283-305.

29.Taraniuk, L., Taraniuk, K. (2016). Methodological basis of risk management system with regard to industrial activities in the course of radical transformations. Economic Annals- XXI, 156 (1-2), 6770. DOI: http://dx.doi.org/10.21003/ea.V156-0015

30.Taylor, Ph. M. (2003). Munitions of the mind: A history of propaganda from the ancient world to the present era. Manchester; New York: Manchester University Press, 353.

31.Teletov, A., Teletova, S., Letunovska, N. (2019). Use of language games in advertising texts as creative approach in advertising management. Periodicals of Engineering and Natural Sciences, $7(2), 458-462$.

32.Tiutiunyk, I., Kobushko, I., Ivaniy, O., \& Flaumer, A. (2019). Innovations in the Management of Tax Gaps in the Economy: Foreign Economic Component. Marketing and Management of Innovations, 3, 112-125.

33.Turchinov, O. V. (1995). Shadow economy: theoretical foundations of research. Kiev: Artek, 51-56

34.Voronova, L. (2003). To the Discussion Questions on the Subject and Method of Financial Law. Bulletin of the Academy of Law Sciences of Ukraine: Coll. of sciences, 2-3(33-34), 313-324.

35.White, R. (1958). A Psychological Warfare Casebook, Baltimore: Johns Hopkins University Press, 617-625.

36. Why is cash still king? A Strategic report on the use of cash by criminal groups as a facilitator for money laundering (2015). European Police Office, 174 